Original scientific paper

UDK: 338.24:339.98

DOI: $10.5937 / J R S 1901021 \mathrm{~S}$

Received: 17 September 2018 / Accepted: 2 October 2018

\title{
The Political Economy of Roadblocks in the Central African Republic
}

PEER SCHOUTEN*

Danish Institute for International Studies, Denmark

ALEXANDRE JAILLON**

International Peace Information Service, Belgium

From September 2016 to September 2017, the International Peace Information Service (IPIS) and the Danish Institute for International Studies (DIIS) conducted a mapping of roadblocks in the Central African Republic. This data collection campaign also features more than 200 interviews with various actors and was combined with data from other reports on roadblocks to form a comprehensive study on the political economy of roadblocks in the Central African Republic.

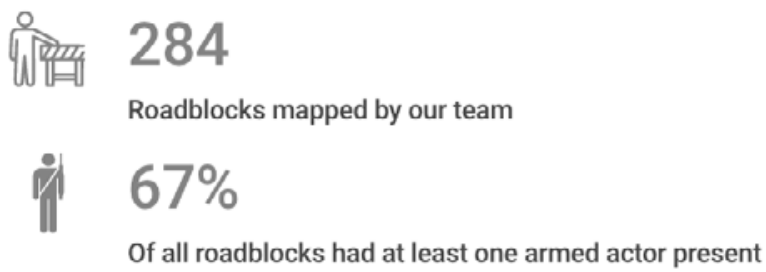

Roadblocks are a manifestation of control over trade routes, a formidable source of funding for all parties to the conflict as well as a mechanism to govern and restrict movement.

Ex-Seleka groups derive a substantial part of their financing from roadblocks; anti-balaka groups try to disrupt enemy logistics; and the government in Bangui depends on the crucial supply corridor to Cameroon, both for consumption goods and import taxes.

\footnotetext{
***pesc@diis.dk

****alexandre.jaillon@ipisresearch.be
} 


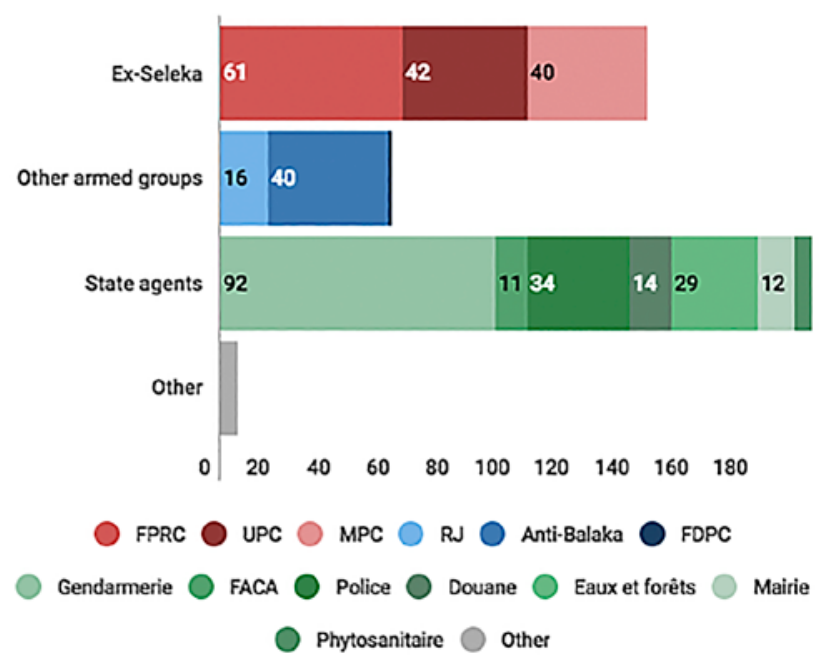

Roadblocks concentrate around three distinct but sometimes overlapping trade circuits: Sudanese long-distance trucking routes (under control of ex-Seleka armed groups), cattle trade routes to supply Bangui (partially under ex-Seleka and partially under government control) and then the supply route connecting Bangui to Cameroon (under nominal government control, with support of the UN mission).

\begin{tabular}{|l|l|l|l|}
\hline Circuit & Principal axes & $\begin{array}{l}\text { Roadblock } \\
\text { operators }\end{array}$ & $\begin{array}{l}\text { Number of } \\
\text { roadblocks }\end{array}$ \\
\hline $\begin{array}{l}\text { Cattle } \\
\text { circuit }\end{array}$ & $\begin{array}{l}\text { Zone around Bambari / Kaga } \\
\text { Bandoro, towards Bangui }\end{array}$ & $\begin{array}{l}\text { MPC / UPC / } \\
\text { FPRC }\end{array}$ & 62 \\
$\begin{array}{l}\text { Sudanese } \\
\text { circuit }\end{array}$ & $\begin{array}{l}\text { Am Dafok - Birao - Ndele - Kaga } \\
\text { Bandoro and Am Dafok - Birao - } \\
\text { Bria - Bambari }\end{array}$ & $\begin{array}{l}\text { FPRC / UPC/ } \\
\text { Anti-Balaka }\end{array}$ & 64 \\
\hline $\begin{array}{l}\text { 'Legal' } \\
\text { circuit }\end{array}$ & Garoua Boulaï - Bangui & State agents & 26 \\
\hline
\end{tabular}

For more information, please refer to Schouten P. and S. P. Kalessopo S.-P. (November 2017). The politics of pillage: the political economy of roadblocks in the Central African Republic. Antwerp/Bangui. Available at http://ipisresearch.be/publication/politicspillage-political-economy-roadblocks-central-african-republic/?_sft_country=centralafrican-republic. 


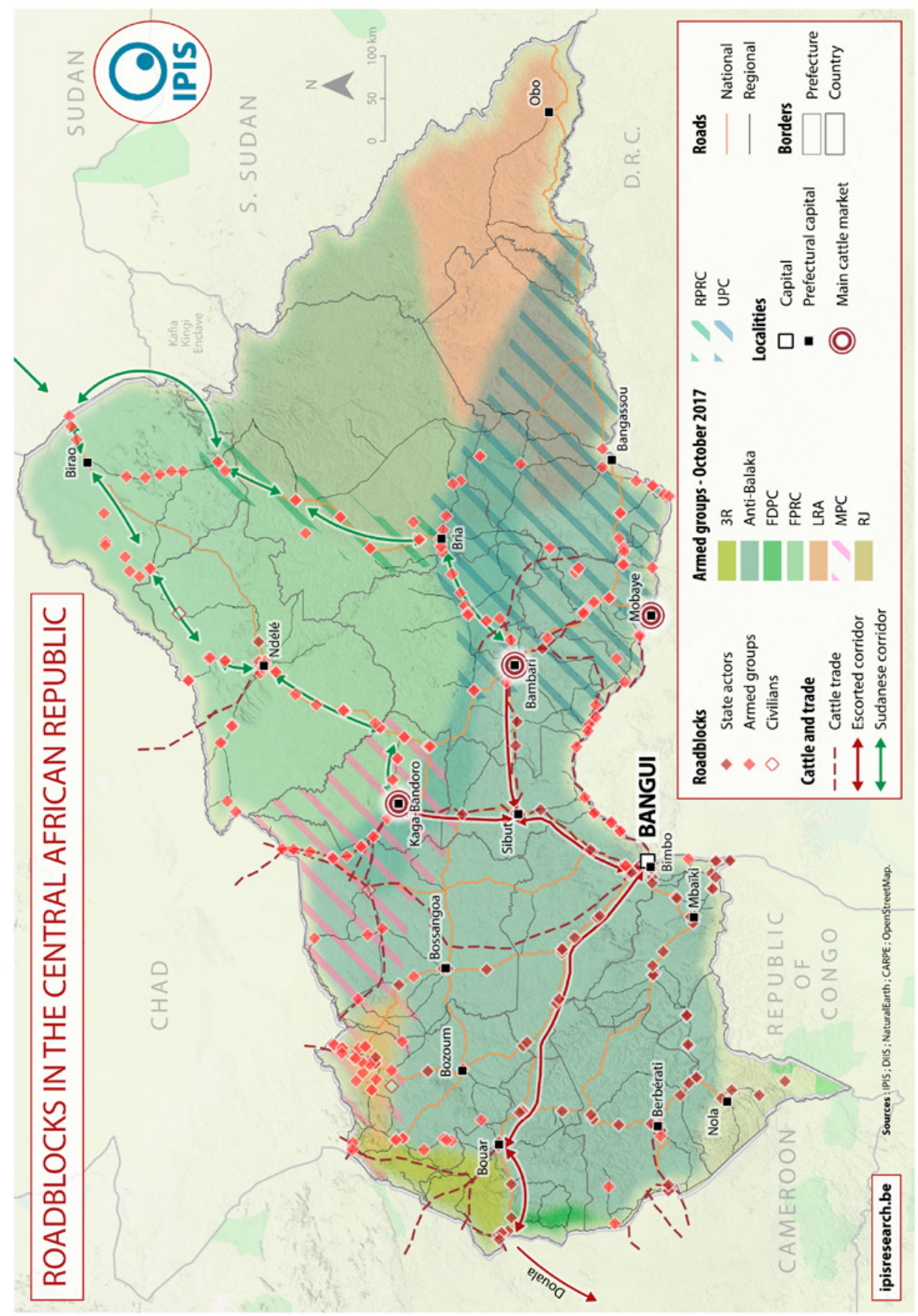

